Eva Baumkamp

\title{
Kommunikation in der Kirche des 3. Jahrhunderts
}

Bischöfe und Gemeinden zwischen Konflikt und Konsens im Imperium Romanum

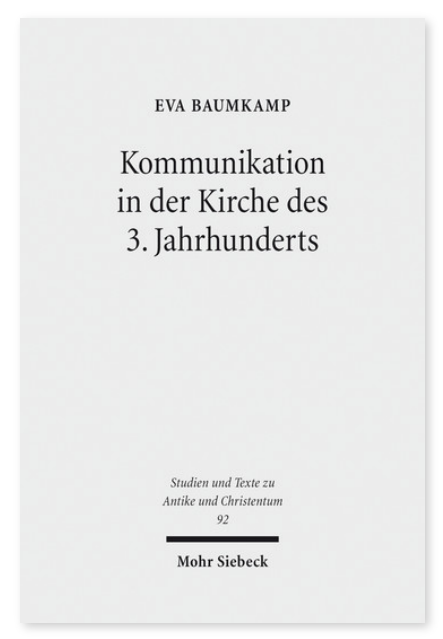

2014. X, 376 Seiten. STAC 92

ISBN 978-3-16-153687-8

DOI 10.1628/978-3-16-153687-8

eBook PDF $114,00 €$

ISBN 978-3-16-153686-1

fadengeheftete Broschur 114,00€
Eva Baumkamp untersucht den Briefverkehr von Bischöfen während der Christenverfolgungen im 3. Jahrhundert im Römischen Reich. Dabei arbeitet sie heraus, wie brieflich Konflikte und Streitigkeiten zwischen Gemeinden und Bischöfen ausgetragen wurden. Die aus der Verfolgungssituation resultierenden Probleme, wie der Umgang mit lapsi, Schismen und Häretikern, wurden reichsweit in Briefen und regional auf persönlichen Treffen der Bischöfe diskutiert. Baumkamp zeigt, dass die Briefe des alexandrinischen Bischofs Dionysius und des karthagischen Bischofs Cyprian ein lebendiges Bild einer sich formierenden Kirche liefern, die über den Austausch von schriftlichen und mündlichen Informationen Strukturen aufbaute und festigte. Die Institutionalisierung des Briefverkehrs und des Synodalwesens leistete damit auch einen entscheidenden Beitrag zum Erfolg des Christentums und der Etablierung der Kirche im Imperium Romanum.

Eva Baumkamp Geboren 1980; Studium der Alten Geschichte, Lateinischen Philologie, Deutschen Philologie und Erziehungswissenschaften in Münster und Clermont-Ferrand; 2011 Promotion; Studienrätin im Hochschuldienst am Seminar für Alte Geschichte/Institut für Epigraphik der WWU Münster.

Jetzt bestellen:

https://mohrsiebeck.com/buch/kommunikation-in-der-kirche-des-3-jahrhunderts-9783161536878?no_cache=1 order@mohrsiebeck.com

Telefon: $+49(0) 7071-923-17$

Telefax: $+49(0) 7071-51104$ 